\title{
Environmentally Friendly Production of D(-) Lactic Acid by Sporolactobacillus nakayamae: Investigation of Fermentation Parameters and Fed-Batch Strategies
}

\author{
Susan Michelz Beitel, ${ }^{1}$ Luciana Fontes Coelho, ${ }^{1}$ Daiane Cristina Sass, ${ }^{1}$ and Jonas Contiero ${ }^{1,2}$ \\ ${ }^{1}$ Department of Biochemistry and Microbiology, Institute of Bioscience, São Paulo State University (UNESP), São Paulo, SP, Brazil \\ ${ }^{2}$ Associate Laboratory IPBEN, UNESP, Av. 24A 1515 CEP, 13506-900, Rio Claro, SP, Brazil \\ Correspondence should be addressed to Jonas Contiero; jconti@rc.unesp.br
}

Received 10 April 2017; Accepted 17 July 2017; Published 10 September 2017

Academic Editor: Joseph Falkinham

Copyright (C) 2017 Susan Michelz Beitel et al. This is an open access article distributed under the Creative Commons Attribution License, which permits unrestricted use, distribution, and reproduction in any medium, provided the original work is properly cited.

\begin{abstract}
The interest in the production of lactic acid has increased due to its wide range of applications. In the present study, the variables that affect fermentative $\mathrm{D}(-)$ lactic acid production were investigated: neutralizing agents, $\mathrm{pH}$, temperature, inoculum percentage, agitation, and concentration of the medium components. An experimental design was applied to determine the optimal concentrations of the medium components and fermentation was studied using different feeding strategies. High production $(122.41 \mathrm{~g} / \mathrm{L})$ and productivity $(3.65 \mathrm{~g} / \mathrm{L} \cdot \mathrm{h})$ were efficiently achieved by Sporolactobacillus nakayamae in $54 \mathrm{~h}$ using a multipulse fedbatch technique with an initial medium containing $35 \mathrm{~g} / \mathrm{L}$ of yeast extract (byproduct of alcohol production), $60 \mathrm{~g} / \mathrm{L}$ of crystallized sugar, and $7.5 \mathrm{~mL} / \mathrm{L}$ of salts. The fermentation process was conducted at $35^{\circ} \mathrm{C}$ and $\mathrm{pH} 6.0$ controlled by $\mathrm{NaOH}$ with a $20 \%$ volume of inoculum and agitation at $125 \mathrm{rpm}$. The production of a high optically pure concentration of $\mathrm{D}(-)$ lactic acid combined with an environmentally friendly $\mathrm{NaOH}$-based process demonstrates that $S$. nakayamae is a promising strain for $\mathrm{D}(-)$ lactic acid production.
\end{abstract}

\section{Introduction}

Lactic acid production has received greater attention due to its considerable potential in biotechnological applications in a wide range of fields as well as the increasing need for new biomaterials, such as biodegradable, biocompatible, and polylactic products [1-3]. This compound is used in the food, chemical, pharmaceutical, and cosmetic industries, is amenable to several chemical conversions, and is used as a precursor for various chemicals and materials [4].

The two optically active isomeric forms of lactic acid are $\mathrm{D}(-)$ and $\mathrm{L}(+)$. Lactic acid can be obtained by chemical synthesis, which inevitably leads to the production of a racemic mixture, whereas the pure enantiomers $\mathrm{L}(+)$ or $\mathrm{D}(-)$ lactic acid can be produced through fermentative processes. The industrial production of $\mathrm{L}(+)$ lactic acid has been extensively reported using several substrates, but few studies have addressed the commercial production of $\mathrm{D}(-)$ lactic acid [5].

Lactic acid is becoming important as an intermediate feedstock used as a monomer for the synthesis of biodegradable polymers [6]. Lactic acid polymer [polylactic acid (PLA)] has three different forms: poly-L-lactic acid, poly-D-lactic acid, and poly-DL-lactic acid [7]. PLA is used in the field of biomedicine in the form of implants, sutures, bone fixation material, and microsphere drug delivery systems due to its excellent biocompatibility and biodegradability $[8,9]$.

For the production of lactic acid, the most important carbohydrates are the disaccharides lactose, maltose, and sucrose [10]. Sucrose enters cells through a specific permease system and is split into glucose and fructose [11]. Since PLA manufacturers require large amount of lactic acid at a relatively low cost, the determination of inexpensive raw materials is important to the feasibility of the microbial 
production of lactic acid [12]. However, the raw materials used as the carbon source must undergo hydrolysis in order to make the sugars assimilable to the bacteria [13]. Thus, pure sugars facilitate downstream processing, whereas inexpensive raw materials as alternative substrates result in an increase in the downstream processing cost due to their relatively high amount of impurities [14].

The fermentation rate depends mainly on $\mathrm{pH}$, temperature, agitation, initial substrate concentration, and the concentration of nitrogenous nutrients [15]. Batch fermentation is widely used in lactic acid production. However, the long fermentation times required with this technique results in low productivity as well as low cell concentrations. The inhibitory effects of the initial substrate concentration on production are also considered a major drawback of this fermentation method. To solve such problems, fed-batch fermentation has been investigated to improve the production, productivity, and yield of lactic acid [3].

Lactic acid is produced by several microorganisms, especially lactic acid bacteria, including genetically modified strains, and some fungi [15-18]. The species Sporolactobacillus nakayamae belongs to the family Sporolactobacillaceae and is an endospore-forming, microaerophilic, mesophilic, homofermentative, and Gram-positive bacterium that exclusively produces $\mathrm{D}(-)$ lactic acid [19]. The aims of the present study were to investigate the influence of the concentration of culture medium components as well the effects of temperature, $\mathrm{pH}$, inoculum percentage, agitation conditions, and $\mathrm{pH}$ controlling agents on $\mathrm{D}(-)$ lactic acid production by $S$. nakayamae. Fed-batch strategies were also studied to increase production and productivity levels of $\mathrm{D}(-)$ lactic acid.

\section{Materials and Methods}

2.1. Bacterium Strain and Culture Medium. The producer strain was the previously identified as Sporolactobacillus nakayamae by Macrogen (Korea). A glucose, yeast extract, and peptone (GYP) medium containing 20\% (v/v) glycerol was used for the maintenance of the strains at $-80^{\circ} \mathrm{C}$. The cells were propagated three times in GYP broth before use and incubated at $35 \pm 1^{\circ} \mathrm{C}$ under stationary conditions until the optical density $\left(\mathrm{OD}_{600}\right)$ reached 2.5 (about $24 \mathrm{~h}$ ).

\subsection{Optimization of Fermentation Media}

2.2.1. Response Surface Methodology. The response surface methodology (RSM) is a set of experimental strategies, mathematical methods, and statistical inferences that enable efficient empirical exploration in a reduced number of experiments [20]. To evaluate the influence of crystallized sugar, yeast extract, and the salts solution $\left(4 \% \mathrm{MgSO}_{4} \cdot 7 \mathrm{H}_{2} \mathrm{O}, 0.16 \%\right.$ $\mathrm{MnSO}_{4} \cdot 4 \mathrm{H}_{2} \mathrm{O}, 0.2 \% \mathrm{FeSO}_{4} \cdot 7 \mathrm{H}_{2} \mathrm{O}$, and $0.2 \% \mathrm{NaCl}$ ) on lactic acid production by $S$. nakayamae, the RSM was used with three replicates at the center point, totaling 17 experiments. The medium used for fermentation was formulated based on the previously used GYP medium. Crystallized sugar is a commercial table sugar found at an affordable price in Brazil. The yeast extract was from Zilor (a major ethanolproducing company in Brazil) and is a byproduct of ethanol
TABLE 1: Variables and respective levels for $\mathrm{D}(-)$ lactic acid production using response surface methodology.

\begin{tabular}{lcccccc}
\hline \multirow{2}{*}{ Variable } & & \multicolumn{5}{c}{ Levels } \\
& & -1.68 & -1 & 0 & 1 & 1.68 \\
\hline Crystallized sugar $(\mathrm{g} / \mathrm{L})$ & $X_{1}$ & 52.8 & 80 & 120 & 160 & 187.2 \\
Yeast extract $(\mathrm{g} / \mathrm{L})$ & $X_{2}$ & 1.4 & 15 & 35 & 55 & 68.6 \\
GYP salt solution $(\mathrm{ml} / \mathrm{L})$ & $X_{3}$ & 0.9 & 3 & 6 & 9 & 11.04 \\
\hline
\end{tabular}

fermentation, which is processed and available at a very low cost. The levels used for encoding the independent variables are shown in Table 1.

Fermentation runs were carried out in $125 \mathrm{~mL}$ Erlenmeyer flasks with an inoculum concentration of $10 \%$, initial $\mathrm{pH}$ at 6.0 , and $5 \% \mathrm{CaCO}_{3}$ used as the $\mathrm{pH}$ neutralizer. The flasks were incubated for 48 hours at $35^{\circ} \mathrm{C}$ under stationary conditions. $\mathrm{D}(-)$ lactic acid and residual sugar were quantified at the end of fermentation. To validate the optimization of the medium composition, five repetitions were carried out using the optimized conditions $(120 \mathrm{~g} / \mathrm{L}$ of crystallized sugar, $35 \mathrm{~g} / \mathrm{L}$ of yeast extract, and $7.5 \mathrm{~mL} / \mathrm{L}$ of GYP salt solution) to confirm the results of the response surface analysis. The results were expressed as mean values. The experimental design was determined using the Statistica 7 software program (StatSoft, Tulsa, USA), which was also used for the analysis of the results.

\subsection{Effect of Culture Conditions on Lactic Acid Production.} Variations of different process parameters ( $\mathrm{pH}, \mathrm{pH}$ controlling agent, temperature, agitation, and inoculum volume) were tested to optimize $\mathrm{D}(-)$ lactic acid production. Fermentation was conducted in a bioreactor (Infors HT Multifors 2) with a working volume of $300 \mathrm{~mL}$ of modified GYP medium ( $35 \mathrm{~g} / \mathrm{L}$ of yeast extract, $120 \mathrm{~g} / \mathrm{L}$ of crystallized sugar, and $7.5 \mathrm{~mL} / \mathrm{L}$ of GYP salts solution) and $10 \%(\mathrm{v} / \mathrm{v})$ of inoculum (except in tests on the influence of inoculum size on lactic acid production). The effect of $\mathrm{pH}$ on lactic acid production was evaluated from 5.0 to 7.0. The influence of the $\mathrm{pH}$ controlling agent was evaluated throughout fermentation by the automatic addition of controlling agents. The influence of temperature was determined from 31 to $39^{\circ} \mathrm{C}$ and the influence of agitation was evaluated from 0 to $150 \mathrm{rpm}$. The production medium was inoculated with different inoculum levels (5 to $25 \% \mathrm{v} / \mathrm{v}$ ). Fermentation was stopped after 48 hours. Samples were withdrawn periodically from the bioreactor to determine the concentrations of sucrose and $\mathrm{D}(-)$ lactic acid. The final fermentation volume was considered for the calculation of lactic acid normalization (production $\mathrm{g} / \mathrm{L}$ $\times$ final volume $\mathrm{mL} /$ initial volume $\mathrm{mL}$ ).

2.4. Fed-Batch Fermentation Strategies. Fed-batch fermentation was performed in a $750 \mathrm{~mL}$ bioreactor (Infors HT Multifors 2) with a working volume of $300 \mathrm{ml}$ of optimized medium containing $35 \mathrm{~g} / \mathrm{L}$ of yeast extract, $7.5 \mathrm{~mL} / \mathrm{L}$ of salts solution, and various amounts of crystallized sugar, as required. Fermentation was run at $35^{\circ} \mathrm{C}$ and $125 \mathrm{rpm}$ with an inoculum volume of $20 \%(\mathrm{v} / \mathrm{v})$. $\mathrm{NaOH}$ was added automatically to control the $\mathrm{pH}$ at 6.0. The feed solution 
contained $730 \mathrm{~g} / \mathrm{L}$ of crystallized sugar and $1 \%$ of yeast extract. In fed-batch fermentation, the feed solution was pumped into the fermenter using a peristaltic pump coupled to a computer. Samples were withdrawn at established intervals for the determination of lactic acid production, sugar consumption, and cell growth. Batch fermentation was conducted with an initial crystallized sugar concentration of $120 \mathrm{~g} / \mathrm{L}$ and $\mathrm{NaOH}$ was added throughout the process to control the $\mathrm{pH}$.

Different feeding strategies were tested to enhance lactic acid production. In the single-pulse fed-batch fermentation, the initial concentration of crystallized sugar was $120 \mathrm{~g} / \mathrm{L}$. The feed solution was supplied once when the residual sugar concentration decreased to $60 \mathrm{~g} / \mathrm{L}$ (at 18 hours) to bring the concentration up to approximately the initial value. Multipulse fed-batch fermentation was conducted with an initial crystallized sugar concentration of $60 \mathrm{~g} / \mathrm{L}$, followed by several additions of the feed solution when the residual sugar concentration was below $40 \mathrm{~g} / \mathrm{L}$. In the constant fed-batch fermentation, the feed solution was added when the residual sugar concentration decreased from the initial $120 \mathrm{~g} / \mathrm{L}$ to $60 \mathrm{~g} / \mathrm{L}$ (at 18 hours) and pumped at a rate of $3 \mathrm{ml} / \mathrm{h}$ until 30 hours. In exponential fed-batch fermentation using the Irirs 6 software, a control strategy developed by Nor et al. (2001) [21] was used, in which the feed rate $(F)$ was determined by (B), which takes into account a mass balance, assuming a constant cell yield on substrate as well as a constant maintenance coefficient throughout the fermentation.

$$
F=\left(\frac{\mu}{Y_{X / S}(S i-S)}\right) V_{0} X_{0} \exp (\mu t)
$$

in which $S$ and $S i$ are, respectively, the crystallized sugar concentration in the medium at the beginning of the feed $(\mathrm{g} / \mathrm{l})$ and in the feed solution $(\mathrm{g} / \mathrm{l}), t$ is culture time $(\mathrm{h}), V_{0}$ is initial culture volume (L), $X$ and $X_{0}$ are, respectively, the cell concentration at the start of feeding $(\mathrm{g} / \mathrm{l})$ and initial cell concentration (g/l), $Y_{X / S}$ is cell yield on sucrose ( $\mathrm{g}$ of cells/g of crystallized sugar), and $\mu$ is the specific cell growth rate $\left(\mathrm{h}^{-1}\right)$. Feeding was begun after 18 hours and lasted for 10 hours.

2.5. Analytical Techniques. The fermented broth was used for the determination of $\mathrm{D}(-)$ lactic acid and residual sucrose. The samples were centrifuged at $7000 \times \mathrm{g}$ for 15 minutes. The supernatant was filtered through a $0.22 \mu \mathrm{m}$ membrane and used for analysis. The concentrations were determined using high-performance liquid chromatography (HPLC) equipped with a Rezex ROA column (Phenomenex, USA) and a differential refracting index detector (RID-A, Shimadzu). The mobile phase $\left(0.005 \mathrm{M} \mathrm{H}_{2} \mathrm{SO}_{4}\right)$ was fed at a flow rate of $0.6 \mathrm{~mL} / \mathrm{min}$ and temperature was maintained at $65^{\circ} \mathrm{C}$. After the medium optimization process, the optical purity of the lactic acid produced was determined by HPLC using a Chirex 3126 phenomenex column with $1 \mathrm{mM}$ of $\mathrm{CuSO}_{4}$ as the mobile phase at $1 \mathrm{~mL} / \mathrm{min}\left(26^{\circ} \mathrm{C}\right)$. Cell growth was determined based on turbidity at $600 \mathrm{~nm}$. The absorbance of the sample measured in a spectrophotometer was correlated to the dry weight mass.

\section{Results and Discussion}

3.1. Influence of Concentration of Medium Components on Lactic Acid Production Using Response Surface Methodology. To obtain greater lactic acid production, the culture conditions were optimized using a factorial design. The independent variables selected for the study were crystallized sugar, yeast extract, and GYP salt solution distributed on two levels, two axial points, and three central points. The results obtained after fermentation were expressed as $\mathrm{g} / \mathrm{l}$ for the amount of lactic acid produced and residual sugar, g/g for yield, and $\mathrm{g} / \mathrm{L} \cdot \mathrm{h}$ for productivity (Table 2). After 48 hours of fermentation, the greatest production was $88.24 \mathrm{~g} / \mathrm{L}$ of $\mathrm{D}(-)$ lactic acid (run 10). In this run, residual sucrose was $25.49 \mathrm{~g} / \mathrm{L}$, productivity was $1.84 \mathrm{~g} / \mathrm{L} \cdot \mathrm{h}$, and the yield was $0.93 \mathrm{~g} / \mathrm{g}$.

Table 3 displays the results of the analysis of variance (ANOVA) for the selected quadratic model. The coefficient of determination $\left(R^{2}=0.84\right)$ suggests that the model explains $84 \%$ of the total variation in the response. Fisher's test demonstrated that the model was significant $[F$ calc $(4.39)>\mathrm{Ft}$ $(3.68)]$ and has a very low probability value $(P$ model $=0.03)$. Among the model terms, interactions $X_{1} X_{1}$ and $X_{2} X_{2}$ were significant with a $95 \%$ probability, demonstrating a negative effect, likely due to catabolite repression by the substrates. The results were submitted to multiple regression analysis methods and yielded the regression equation $(\mathrm{C})$ :

$$
\begin{aligned}
Y= & 85.34+3.93 X_{1}-9.62 X_{1} X_{1}+3.44 X_{2} \\
& -13.78 X_{2} X_{2}-0.02 X_{3}-2.88 X_{3} X_{3}-4,89 X_{1} X_{2} \\
& +4,89 X_{1} X_{3}+5.01 X_{2} X_{3}
\end{aligned}
$$

in which $Y$ is the predicted response $(\mathrm{D}(-)$ lactic acid production) and $X_{1}, X_{2}, X_{3}$ are, respectively, the coded values of the test variables crystallized sugar, yeast extract, and salt solution. The response for the regression equation is plotted in Figure 1. The graphs shows the interaction of the variables and optimum levels for $\mathrm{D}(-)$ lactic acid production.

Based on the response surface graphs, the medium components that induced the greatest $\mathrm{D}(-)$ lactic acid production were $120 \mathrm{~g} / \mathrm{L}$ of crystallized sugar, $35 \mathrm{~g} / \mathrm{L}$ of yeast extract, and $7.5 \mathrm{~mL} / \mathrm{L}$ of salt solution. The concentration of crystallized sugar was selected considering residual sucrose, which should not exceed $10 \mathrm{~g} / \mathrm{L}$. The validation of the model for lactic acid production optimization was performed using the selected concentrations in five replicates and the results were expressed as mean values. Under these conditions, production was $89.69 \mathrm{~g} / \mathrm{L}$ of $\mathrm{D}(-)$ lactic acid, productivity was $1.87 \mathrm{~g} / \mathrm{Lh}$, the yield was $0.96 \mathrm{~g} / \mathrm{g}$, and residual sucrose was $26.67 \mathrm{~g} / \mathrm{L}$. These results confirm the validity and usefulness of the model equation. The optimized culture medium was analyzed using HPLC with a chiral column to determine the optical purity of the lactic acid produced. This analysis revealed $98.97 \% \mathrm{D}(-)$ lactic acid and $1.03 \% \mathrm{~L}(+)$ lactic acid, thereby demonstrating the high optical purity characteristic of S. nakayamae.

3.2. Effects of Neutralizing Agents on D(-) Lactic Acid Production. A drop in $\mathrm{pH}$ occurs during lactic acid fermentation 
TABLE 2: RSM design with real values and experimental results for lactic acid production, productivity, yield, and residual sugar concentration.

\begin{tabular}{|c|c|c|c|c|c|c|c|}
\hline \multirow{3}{*}{ Run } & \multicolumn{3}{|c|}{ Experimental factors } & \multicolumn{4}{|c|}{ Response variable } \\
\hline & Crystallized sugar (g/L) & Yeast extract $(\mathrm{g} / \mathrm{L})$ & Salt solution $(\mathrm{mL} / \mathrm{L})$ & Lactic acid & Productivity & $Y_{\mathrm{p} / \mathrm{s}}$ & Residual sugar \\
\hline & $X_{1}$ & $X_{2}$ & $X_{3}$ & $\mathrm{~g} / \mathrm{L}$ & $\mathrm{g} / \mathrm{Lh}$ & $\mathrm{g} / \mathrm{g}$ & $\mathrm{g} / \mathrm{L}$ \\
\hline 1 & 80.0 & 15.0 & 3.0 & 65.13 & 1.36 & 0.81 & 0 \\
\hline 2 & 160.0 & 15.0 & 3.0 & 59.02 & 1.23 & 0.75 & 81.41 \\
\hline 3 & 80.0 & 55.0 & 3.0 & 61.32 & 1.28 & 0.97 & 17.00 \\
\hline 4 & 160.0 & 55.0 & 3.0 & 58.36 & 1.22 & 0.88 & 93.34 \\
\hline 5 & 80.0 & 15.0 & 9.0 & 26.64 & 0.56 & 0.97 & 52.44 \\
\hline 6 & 160.0 & 15.0 & 9.0 & 62.84 & 1.31 & 0.84 & 85.00 \\
\hline 7 & 80.0 & 55.0 & 9.0 & 65.59 & 1.37 & 0.99 & 14.03 \\
\hline 8 & 160.0 & 55.0 & 9.0 & 59.51 & 1.24 & 0.82 & 87.35 \\
\hline 9 & 120.0 & 35.0 & 0.9 & 71.01 & 1.48 & 0.98 & 47.20 \\
\hline 10 & 120.0 & 35.0 & 11.0 & 88.24 & 1.84 & 0.93 & 25.49 \\
\hline 11 & 120.0 & 1.40 & 6.0 & 44.10 & 0.92 & 0.98 & 74.86 \\
\hline 12 & 120.0 & 68.5 & 6.0 & 53.53 & 1.12 & 0.99 & 65.84 \\
\hline 13 & 52.8 & 35.0 & 6.0 & 50.86 & 1.06 & 0.96 & 0.00 \\
\hline 14 & 187.2 & 35.0 & 6.0 & 70.31 & 1.46 & 0.77 & 96.34 \\
\hline 15 & 120.0 & 35.0 & 6.0 & 87.98 & 1.83 & 0.98 & 30.64 \\
\hline 16 & 120.0 & 35.0 & 6.0 & 81.85 & 1.71 & 0.94 & 33.34 \\
\hline 17 & 120.0 & 35.0 & 6.0 & 85.33 & 1.78 & 0.89 & 24.35 \\
\hline
\end{tabular}

$X_{1}=$ crystallized sugar; $X_{2}=$ yeast extract; $X_{3}=$ salt solution. Culture conditions: $35^{\circ} \mathrm{C}$, initial pH at 6.0 neutralized by $5 \% \mathrm{CaCO}_{3}$, stationary fermentation, and $10 \%$ inoculum. Fermentation was conducted for 48 hours.

TABLE 3: ANOVA with estimated regression coefficients for $\mathrm{D}(-)$ lactic acid production.

\begin{tabular}{|c|c|c|c|c|c|c|}
\hline Source & Coefficient & Sum of squares & Degrees of freedom & Mean square & $F$ ratio & $P$ \\
\hline$X_{1}$ & 3.93 & 211.632 & 1 & 211.632 & 2.351 & 0.169 \\
\hline$X_{1} X_{1}$ & -9.62 & 1043.505 & 1 & 1043.505 & 11.594 & $0.011^{*}$ \\
\hline$X_{2}$ & 3.44 & 161.814 & 1 & 161.814 & 1.798 & 0.221 \\
\hline$X_{2} X_{2}$ & -13.78 & 2141.408 & 1 & 2141.408 & 23.794 & $0.001^{*}$ \\
\hline$X_{3}$ & -0.02 & 0.005 & 1 & 0.005 & 0.000 & 0.994 \\
\hline$X_{3} X_{3}$ & -2.88 & 94.113 & 1 & 94.113 & 1.045 & 0.340 \\
\hline$X_{1} X_{2}$ & -4.89 & 191.395 & 1 & 191.395 & 2.126 & 0.188 \\
\hline$X_{1} X_{3}$ & 4.89 & 191.982 & 1 & 191.982 & 2.133 & 0.187 \\
\hline$X_{2} X_{3}$ & 5.01 & 200.901 & 1 & 200.901 & 2.232 & 0.178 \\
\hline Model & - & 3557.58 & 9 & 395.28 & 4.39 & 0.03 \\
\hline Error & - & 629.97 & 7 & 89.99 & - & - \\
\hline Lack of fit & - & 611.07 & 5 & 122.21 & 12.93 & 0.07 \\
\hline Pure error & - & 18.90 & 2 & 9.45 & - & - \\
\hline Total & - & 4187.55 & 16 & - & - & - \\
\hline
\end{tabular}

$X_{1}=$ crystallized sugar; $X_{2}=$ yeast extract; $X_{3}=$ salt solution. ${ }^{*}$ Statistically significant at $95 \%$ probability level.

and the microorganism is unable to continue the fermentation. Thus, neutralization is essential and several bases can be used for this purpose, which is closely related to downstream processing [22]. The effect of different neutralizing agents $\left(\mathrm{KOH} 10 \mathrm{~N}, \mathrm{Ca}(\mathrm{OH})_{2} 6 \mathrm{~N}, \mathrm{NaOH} 10 \mathrm{~N}, 5 \% \mathrm{CaCO}_{3}\right.$, $6 \% \mathrm{CaCO}_{3}$, and $27 \% \mathrm{NH}_{4} \mathrm{OH}$ ) on lactic acid production was investigated. Fermentation was conducted using the optimized culture medium at $35^{\circ} \mathrm{C}$ and $\mathrm{pH} 6.0$ controlled by neutralizing agents automatically added to the process, except $\mathrm{CaCO}_{3}$, which was added to the fermentation vessel at the beginning of the process. Fermentation was conducted for 48 hours.

Table 4 displays the results of the $\mathrm{pH}$ neutralizing tests. Based on these data, $\mathrm{NaOH}$ was selected as the neutralizing agent considering the practicality of the process and the maximum volumetric lactic acid production $(103.71 \mathrm{~g} / \mathrm{L})$, productivity $(2.16 \mathrm{~g} / \mathrm{L} \cdot \mathrm{h})$, and yield $(0.94 \mathrm{~g} / \mathrm{g})$. No residual sugar was found in this experiment, which is interesting from the standpoint of further lactic acid purification and polymerization. Moreover, $\mathrm{NaOH}$ used as a $\mathrm{pH}$ controller in 


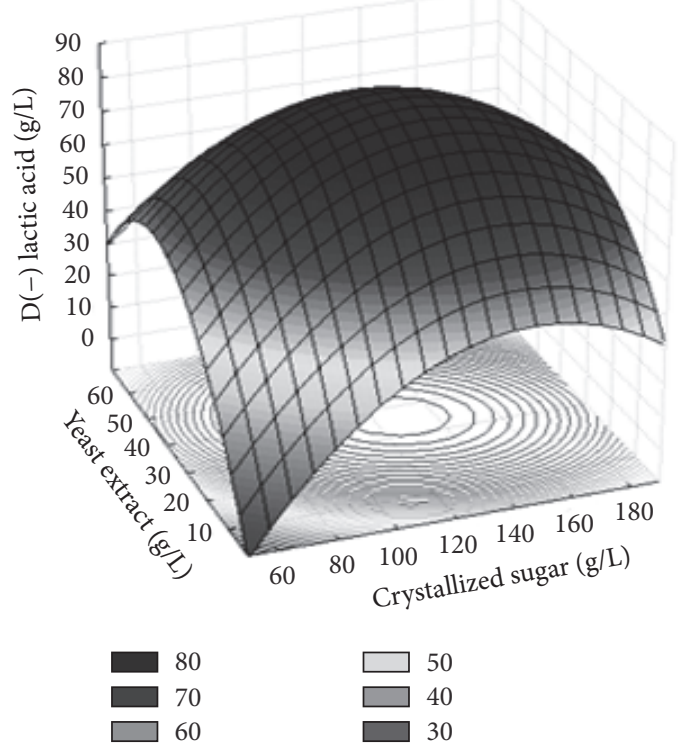

(a)

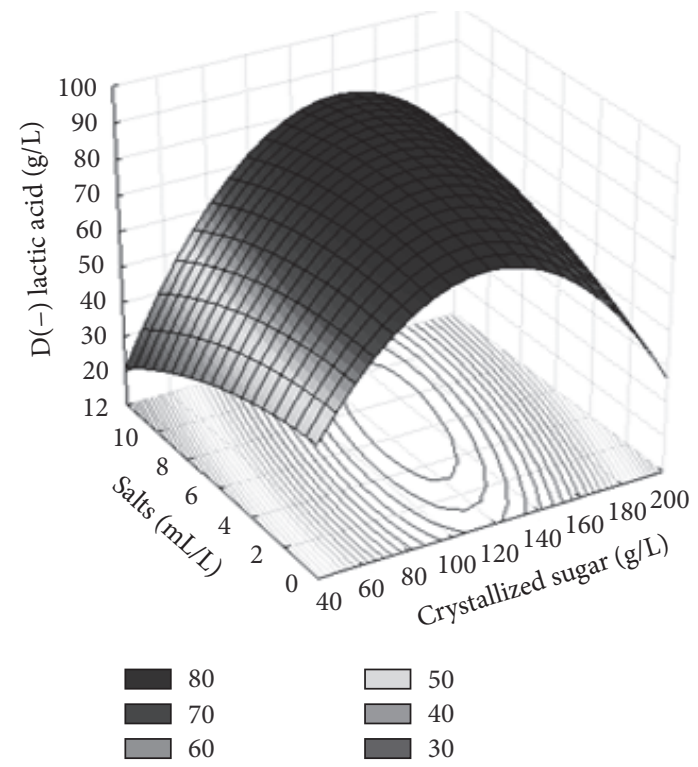

(b)

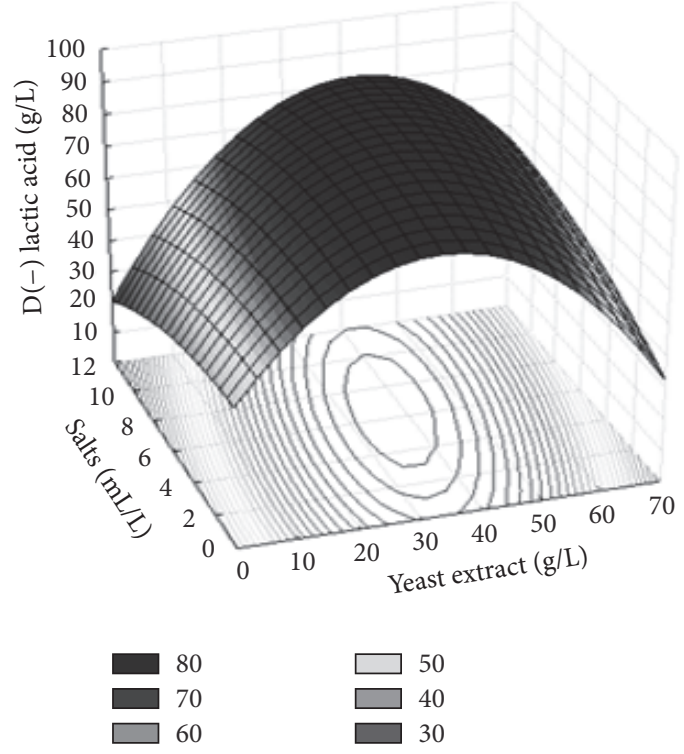

(c)

FIGURE 1: Response surface for lactic acid production by S. nakayamae. Interactions between (a) yeast extract and crystallized sugar, (b) salts and crystallized sugar, and (c) yeast extract and salts.

TABLE 4: Comparison of D-lactic acid fermentation by S. nakayamae using different neutralizing agents.

\begin{tabular}{|c|c|c|c|c|c|c|c|}
\hline Neutralizing agent & $\begin{array}{l}\text { Price } \\
\mathrm{R} \$ / \mathrm{kg}\end{array}$ & $\begin{array}{l}\text { Used in fermentation } \\
\mathrm{g} / 300 \mathrm{~mL}\end{array}$ & $\begin{array}{c}\text { Cost in fermentation } \\
\mathrm{R} \$\end{array}$ & $\begin{array}{c}\mathrm{D}(-) \text { lactic acid } \\
\mathrm{g} / \mathrm{L}\end{array}$ & $\begin{array}{c}P \\
\mathrm{~g} / \mathrm{L} \cdot \mathrm{h}\end{array}$ & $\begin{array}{l}Y_{\mathrm{p} / \mathrm{s}} \\
\mathrm{g} / \mathrm{g}\end{array}$ & $\begin{array}{l}\mathrm{RS}^{*} \\
\mathrm{~g} / \mathrm{L}\end{array}$ \\
\hline $\mathrm{CaCO}_{3} 5 \%$ & 44.00 & 15.00 & 0.66 & 91.17 & 1.90 & 0.90 & 11.76 \\
\hline $\mathrm{Ca}(\mathrm{OH})_{2}$ & 40.00 & 11.11 & 0.44 & 88.95 & 1.85 & 0.81 & 3.52 \\
\hline $\mathrm{NaOH}$ & 51.00 & 12.00 & 0.61 & 103.71 & 2.16 & 0.94 & 0.00 \\
\hline $\mathrm{KOH}$ & 86.00 & 5.61 & 0.48 & 84.45 & 1.98 & 0.79 & 0.00 \\
\hline $\mathrm{NH}_{4} \mathrm{OH}$ & 17.20 & 9.17 & 0.17 & 16.05 & 0.33 & 0.13 & 88.85 \\
\hline $\mathrm{CaCO}_{3} 6 \%$ & 44.00 & 18.00 & 0.79 & 37.46 & 0.78 & 0.85 & 65.99 \\
\hline
\end{tabular}

$P=$ productivity; $Y_{\mathrm{p} / \mathrm{s}}=$ Yield; RS = residual sucrose. ${ }^{*}$ Normalized lactic acid and sucrose titer was calculated from measured titer (not shown) from fermentation broth with dilution ratio of neutralizing agent used. Productivity and yield were calculated considering normalized data. 
fermentation processes does not generate precipitated waste, making it environmentally friendly [23]. In contrast, the ammoniacal solution was not an appropriate neutralizing agent, as demonstrated by the low lactic acid production $(16.05 \mathrm{~g} / \mathrm{L})$. This result is in agreement with data reported by other authors studying lactic acid production by Rhizopus oryzae, with $24.9 \mathrm{~g} / \mathrm{L}$ of lactic acid produced when an ammoniacal solution was used as neutralizing agent, as a high concentration of ammonia can be toxic to microbial cells [24].

Calcium carbonate $\left(\mathrm{CaCO}_{3}\right)$ is often used as such a $\mathrm{pH}$ controlling agent [25] and yielded the second highest $\mathrm{D}(-)$ lactic acid production $(91.17 \mathrm{~g} / \mathrm{L})$ when used at a proportion of $5 \%$ in the present study. In contrast, the $6 \%$ proportion inhibited microorganism growth. The low solubility of $\mathrm{CaCO}_{3}$ in the fermentation broth could cause problems in the subsequent purification process, as the most used recovery method consumes lime as well as sulfuric acid and also produces a large quantity of calcium sulfate sludge as solid waste [26].

When $\mathrm{Ca}(\mathrm{OH})_{2} 6 \mathrm{~N}$ was used, $88.95 \mathrm{~g} / \mathrm{L}$ of $\mathrm{D}(-)$ lactic acid was achieved. Although this neutralizing agent is affordable, it is necessary to stir the solution constantly using a magnetic plate/stove during fermentation to prevent clogs in the base feeding tubes, resulting in an added cost to the process. A previous study reports $\mathrm{D}(-)$ lactic acid production of $127 \mathrm{~g} / \mathrm{L}$ using $\mathrm{Ca}(\mathrm{OH})_{2}$ as the neutralizing agent on the laboratory scale; the author states that the lower osmotic pressure derived from this neutralizing base may be partially responsible for the facilitation of D-lactic acid fermentation [27].

As shown in Figure 2, the process ended without any residual sugar when $\mathrm{NaOH}$ or $\mathrm{KOH}$ was used as the neutralizing agent. Besides lactic acid production of $84.45 \mathrm{~g} / \mathrm{L}$ using $\mathrm{KOH}$ neutralization, this agent is unaffordable for large scale production. The figure shows the time course of lactic acid and residual sucrose concentration using different neutralizing agents for 48 hours.

\subsection{Effects of Culture Conditions on Lactic Acid Production}

3.3.1. Influence of Temperature and $p H$ on $D(-)$ Lactic Acid Production. The capacity of microorganisms to produce lactic acid is influenced by conditions, such as temperature, $\mathrm{pH}$, agitation, and inoculum percentage, the optimization of which is essential. Temperature and $\mathrm{pH}$ are important parameters that affect the fermentation process [28]. $\mathrm{D}(-)$ lactic acid produced by the $S$. nakayamae was efficient at $\mathrm{pH}$ 6.0 , with an optimum temperature at $35^{\circ} \mathrm{C}$ (Figures 3(a) and 3 (b)), reaching a production of $99.43 \mathrm{~g} / \mathrm{L}$ with a low level of residual sucrose $(3.45 \mathrm{~g} / \mathrm{L})$. The productivity and yield under these conditions were $2.07 \mathrm{~g} / \mathrm{L} \cdot \mathrm{h}$ and $0.91 \mathrm{~g} / \mathrm{g}$, respectively (data not shown). Other authors report achieving a high Dlactate concentration using strains of Sporolactobacillus sp. at $42^{\circ} \mathrm{C}[29,30]$. Temperature exerts an influence on the activity of metabolic cells. Most bacteria that convert sugar into lactic acid are classified as either thermophilic or mesophilic, with optimum growth between 20 and $40^{\circ} \mathrm{C}$ [31].

The optimum $\mathrm{pH}$ for lactic acid production by microorganisms ranges from 5.0 to 7.0 and is dependent on the

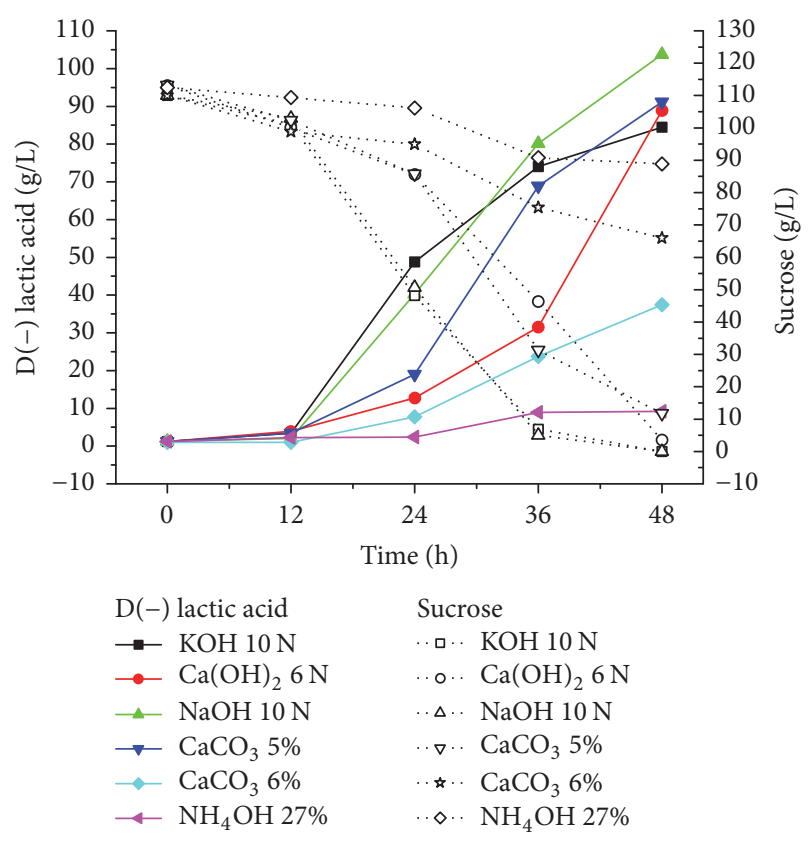

FIgURE 2: Time course of lactic acid and residual sucrose concentration using different neutralizing agents $\left[\mathrm{KOH}, \mathrm{Ca}(\mathrm{OH})_{2}, \mathrm{NaOH}\right.$, $\mathrm{CaCO}$, and $\mathrm{NH}_{4} \mathrm{OH}$. Culture conditions: GYP modified medium, $35^{\circ} \mathrm{C} \mathrm{pH} \mathrm{6.0,10 \%} \mathrm{(v/v)} \mathrm{inoculums,} 100 \mathrm{rpm}$.

species of microorganism [32]. In the present study, lactic acid production decreased significantly when the $\mathrm{pH}$ was lower than 6.0 (Figure 3(b)). Likewise, previous authors report $52.37 \mathrm{~g} / \mathrm{L}$ of $\mathrm{D}(-)$ lactic acid by Lactobacillus sp. LMI8 when fermentation was conducted at $\mathrm{pH} 6.0$ [33].

3.3.2. Effect of Agitation and Inoculum Size on D(-) Lactic Acid Fermentation. The influence of agitation and inoculum size on $\mathrm{D}(-)$ lactic acid production was investigated, the results of which are shown in Figure 4 . High $\mathrm{D}(-)$ lactic acid production $(107.67 \mathrm{~g} / \mathrm{L})$ was found when agitation was $125 \mathrm{rpm}$. Moreover, high productivity $(2.24 \mathrm{~g} / \mathrm{Lh})$ and yield $(0.98 \mathrm{~g} / \mathrm{g})$ (data not shown) were achieved and no residual sucrose was found under this condition. Stationary conditions were inefficient for lactic acid production $(65.03 \mathrm{~g} / \mathrm{L})$, possibly due to insufficient homogenization of the culture medium. In contrast, a previous study reported no difference in lactic acid production by Lactobacillus casei under stationary conditions or agitation at $100 \mathrm{rpm}$ [34].

Maximum lactic acid production (113.73 g/L) was obtained with low residual sucrose $(3.37 \mathrm{~g} / \mathrm{L})$ when using $20 \%(\mathrm{v} / \mathrm{v})$ of inoculum in the culture medium. Moreover, productivity was $2.37 \mathrm{~g} / \mathrm{Lh}$ and yield was $0.98 \mathrm{~g} / \mathrm{g}$ under this condition (data not shown). The low lactic acid production $(82.34 \mathrm{~g} / \mathrm{L})$ with $5 \%(\mathrm{v} / \mathrm{v})$ inoculum could be attributed to the low density of the starter culture. In a previous study addressing the influence of inoculum size on $\mathrm{L}(+)$ lactic acid production by Rhizopus oryzae ASC081, production decreased when the inoculum size was less than $10 \%$ due to an inadequate enzymatic efficiency [35]. 


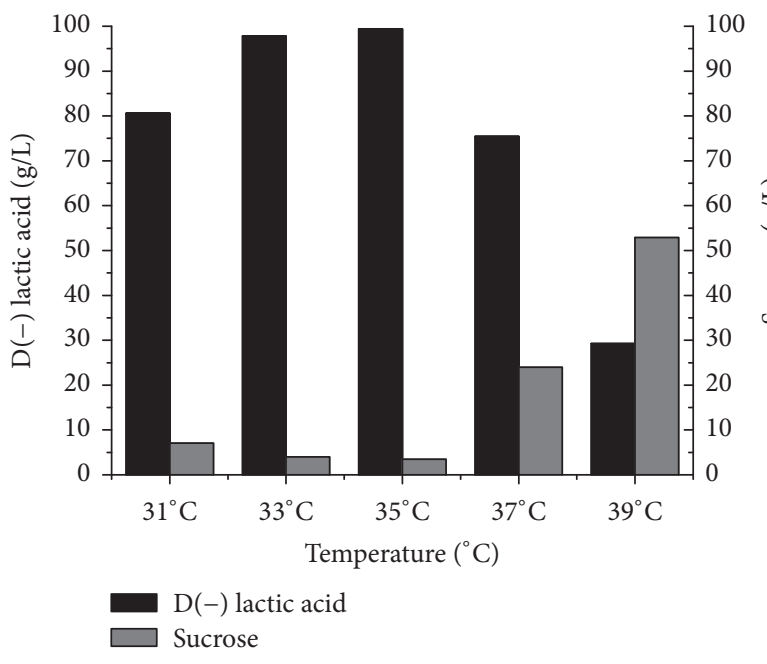

(a)

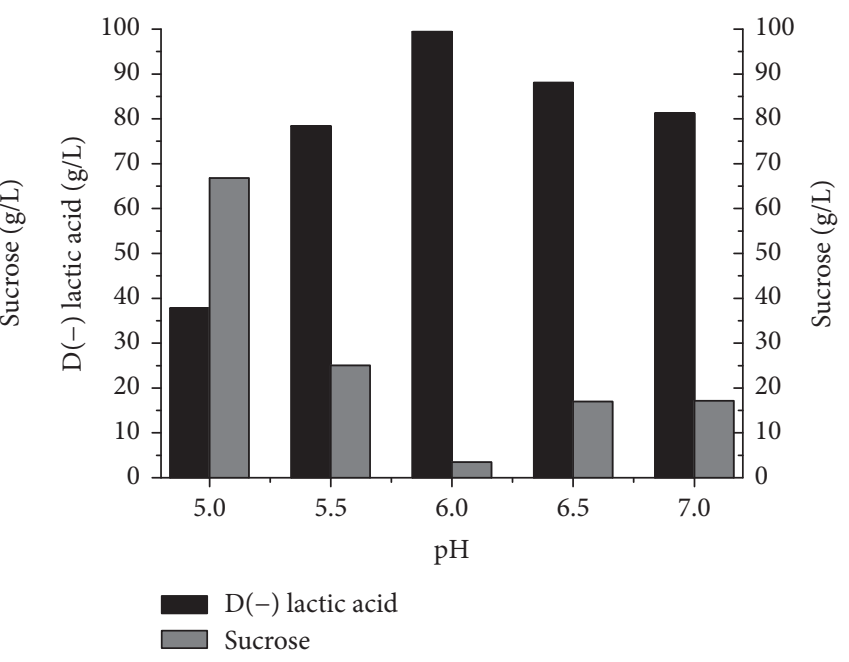

(b)

FIGURE 3: Effect of (a) temperature and (b) $\mathrm{pH}$ on $\mathrm{D}(-)$ lactic acid production and sucrose consumption by S. nakayamae. Culture conditions: GYP modified medium ( $120 \mathrm{~g} / \mathrm{L}$ of crystallized sugar, $35 \mathrm{~g} / \mathrm{L}$ of yeast extract, and 7.5 salt solution) with $\mathrm{NaOH} 10 \mathrm{~N}$ as $\mathrm{pH}$ neutralizing agent. (a) GYP modified medium at $\mathrm{pH} 6.0$, under $100 \mathrm{rpm}$, with $10 \%$ inoculum; (b) GYP modified medium at $35^{\circ} \mathrm{C}$, under $100 \mathrm{rpm}$, with $10 \%$ inoculum.

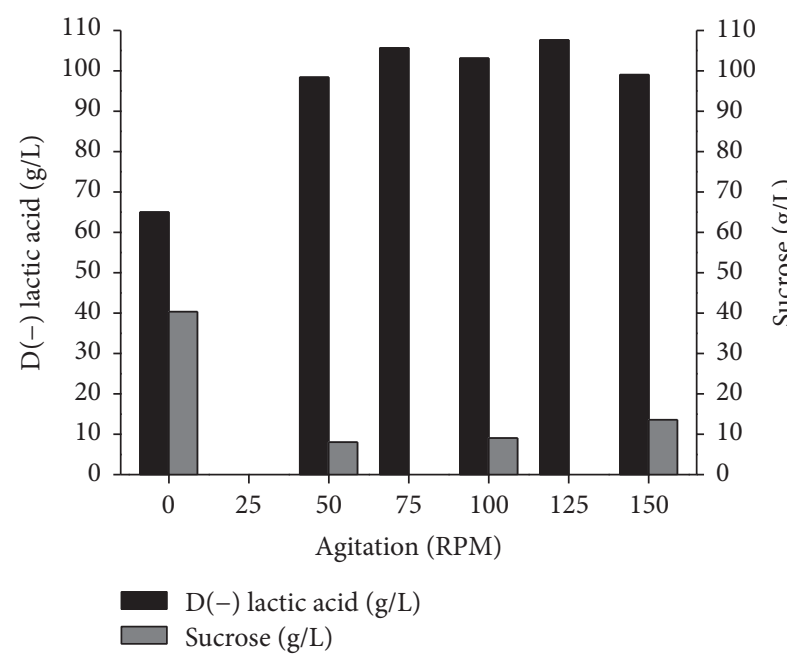

(a)

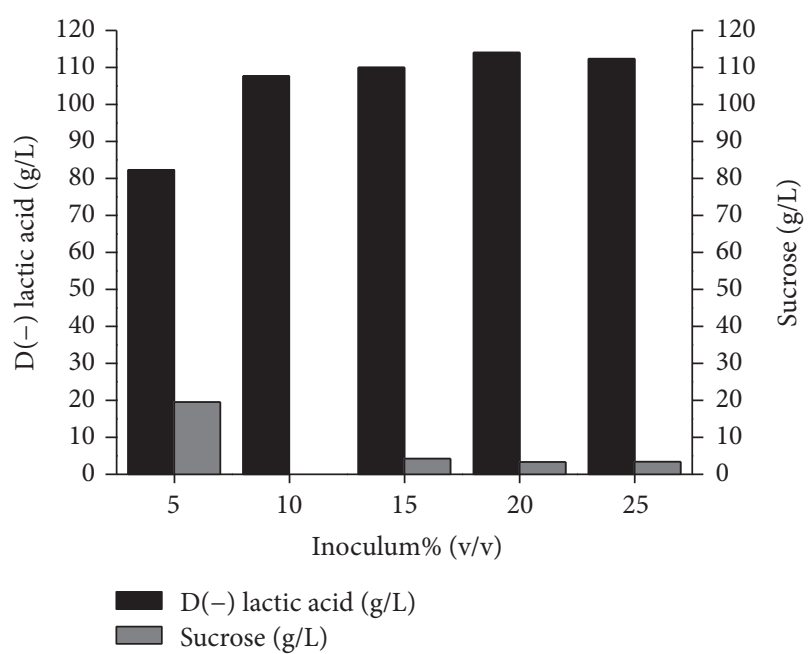

(b)

FIGURE 4: Effect of (a) agitation and (b) inoculum size on $\mathrm{D}(-)$ lactic acid production and sucrose consumption by $S$. nakayamae. Culture conditions: GYP modified medium ( $120 \mathrm{~g} / \mathrm{L}$ crystallized sugar, $35 \mathrm{~g} / \mathrm{L}$ yeast extract, and $7.5 \mathrm{~mL} / \mathrm{L}$ salt solution) with $\mathrm{NaOH} 10 \mathrm{~N}$ as $\mathrm{pH}$ neutralizing agent. (a) GYP modified medium at $35^{\circ} \mathrm{C}, \mathrm{pH} 6.0$, with $10 \%$ inoculum; (b) GYP modified medium at $35^{\circ} \mathrm{C}$ and $\mathrm{pH} 6.0$ under $125 \mathrm{rpm}$.

3.4. Fed-Batch Fermentation Strategies. Fed-batch cultures were developed to maximize the production and productivity of $\mathrm{D}(-)$ lactic acid by $S$. nakayamae. The time courses of cell growth, sucrose consumption, and $\mathrm{D}(-)$ lactic acid production during the batch and fed-batch cultures (pulse and multipulse) are shown in Figure 5.

Maximum $\mathrm{D}(-)$ lactic acid production $(126.64 \mathrm{~g} / \mathrm{L})$ was obtained at the end of the single-pulse fed-batch (Figure $5(\mathrm{~b}))$. The highest cell density $(11.67 \mathrm{~g} / \mathrm{L})$ was also found in this culture. However, it took 78 hours to achieve these results, with productivity of $1.62 \mathrm{~g} / \mathrm{L} \cdot \mathrm{h}$. Using pulse fed-batch to improve $\mathrm{D}(-)$ lactic acid productivity by Sporolactobacillus inulinus YBS1-5, Bai et al. (2016) [36] achieved $107 \mathrm{~g} / \mathrm{L}$ of lactic acid and productivity of $1.19 \mathrm{~g} / \mathrm{L} \cdot \mathrm{h}$ at $90 \mathrm{~h}$.

The fed-batch fermentation with two pulses (Figure 5(c)) initiated at low levels of sucrose demonstrated promising results, achieving the second greatest lactic acid production $(122.64 \mathrm{~g} / \mathrm{L})$ at 54 hours; at this time, the residual sugar concentration was $13.47 \mathrm{~g} / \mathrm{L}$. Moreover, this process had the highest productivity at 13 hours $(3.65 \mathrm{~g} / \mathrm{L} \cdot \mathrm{h})$ in comparison to 

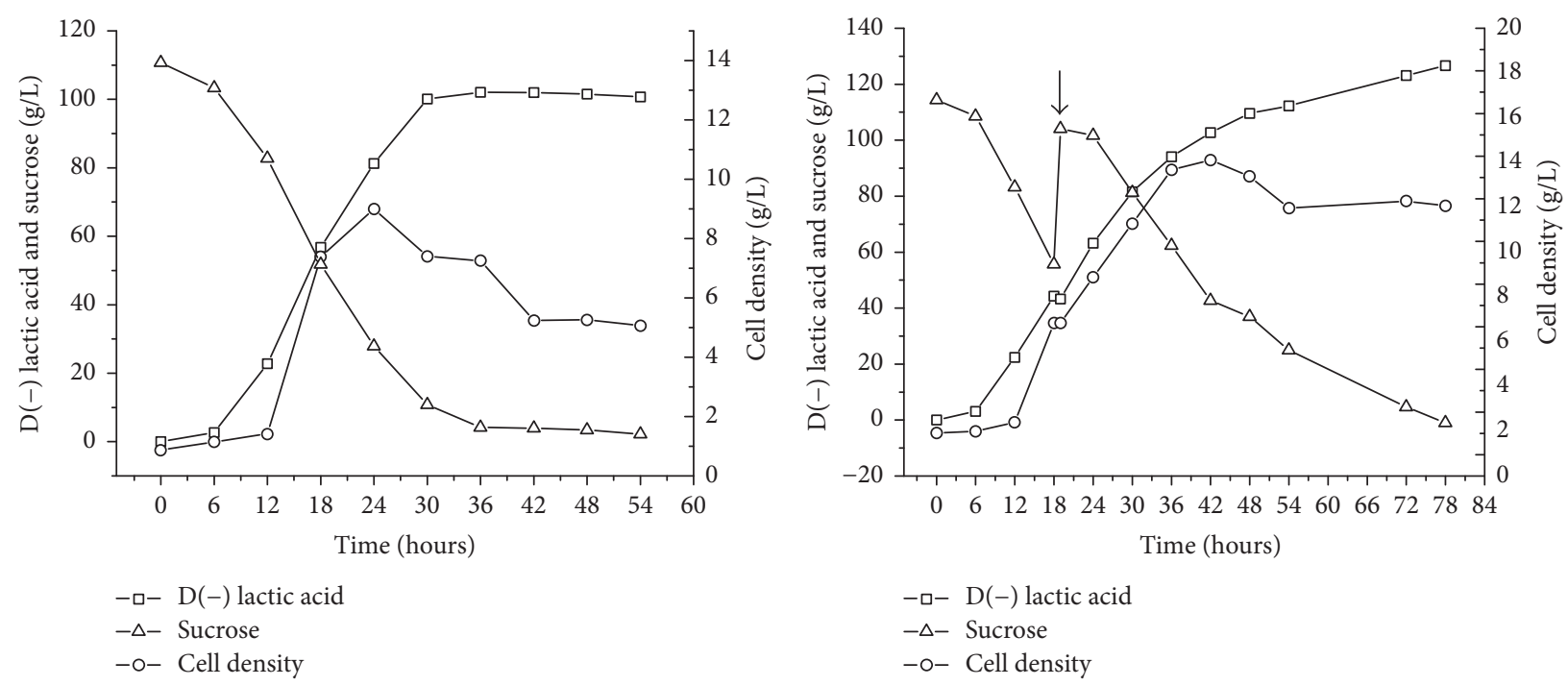

(a)

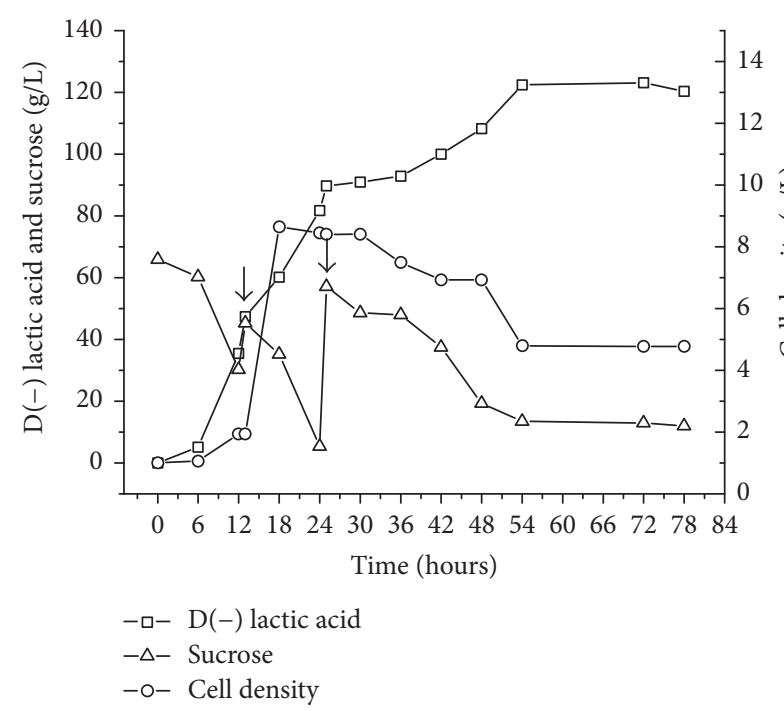

(c) (b)

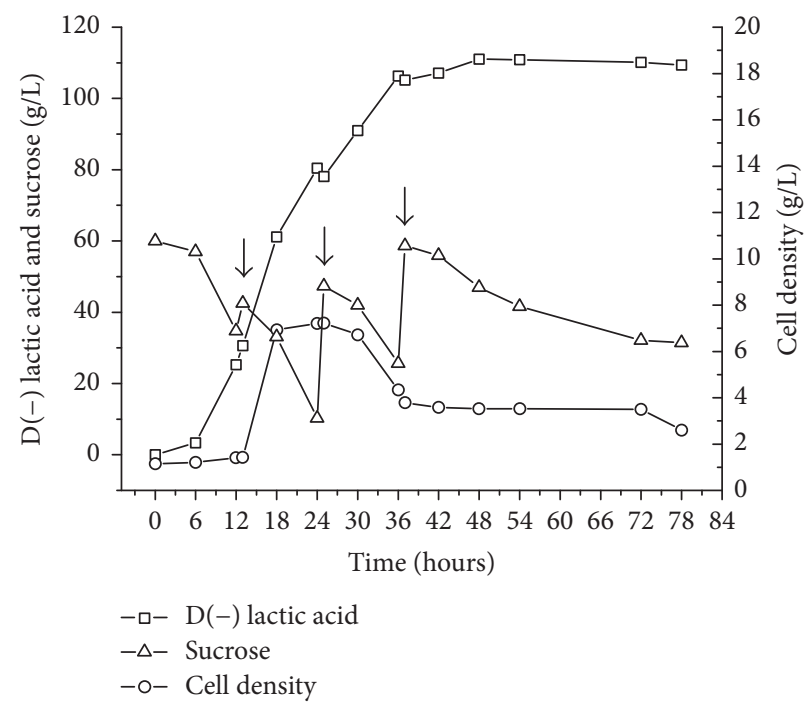

(d)

Figure 5: Time courses of sucrose consumption, D(-) lactic acid production, and cell growth in batch fermentation (a), pulse fed-batch (b), and multipulse fed-batch fermentation ( $\mathrm{c}$ and d) by S. nakayamae. Experimental conditions: medium containing $35 \mathrm{~g} / \mathrm{L}$ of yeast extract and $7.5 \mathrm{~mL} / \mathrm{L}$ of GYP salts and crystallized sugar (as required); $\mathrm{pH} 6.0, \mathrm{NaOH} 10 \mathrm{~N}$ as controlling agent, temperature at $35^{\circ} \mathrm{C}, 125 \mathrm{rpm}$, and $20 \%$ of inoculum $(\mathrm{v} / \mathrm{v})$.

the other methods. Bai et al. (2003) [37] report similar results studying fed-batch fermentation for $\mathrm{L}(+)$ lactic production by Lactobacillus lactis.

The multipulse, fed-batch culture with three pulses (Figure 5(d)) was not satisfactory. The amount of sugar added likely caused high osmotic pressure in the cells, resulting in plasmolysis and decreasing both the fermentation rate and sugar utilization. This finding is in agreement with data described by Kotzamanidis et al. (2002) [38]. Other authors report greater production by Sporolactobacillus sp. CASD using a multipulse strategy in comparison to a single pulse [30].

The final $\mathrm{D}(-)$ lactic acid concentration with the constant feed rate and exponential fed-batch systems was $119.03 \mathrm{~g} / \mathrm{L}$ and $121.02 \mathrm{~g} / \mathrm{L}$, respectively (Figures 6(a) and 6(b)). These strategies were not satisfactory, as the sucrose concentration was greater than $20 \mathrm{~g} / \mathrm{L}$ at the end of the process. Although productivity values were low at the end of the process, the highest productivity was $3.15 \mathrm{~g} / \mathrm{L} \cdot \mathrm{h}$ with the exponential fed-batch method at $24 \mathrm{hrs}$ and $3.06 \mathrm{~g} / \mathrm{L} \cdot \mathrm{h}$ with the constant feed rate at 30 hrs. Bernardo et al. (2016) [39] report similar results using a constant feed rate for $\mathrm{L}(+)$ lactic acid production by Lactobacillus rhamnosus B103. The authors report a slight increase in lactic acid production, but a high residual substrate concentration at the end of the process. Other authors report a $56.5 \%$ improvement in $\mathrm{L}(+)$ lactic acid production using exponential feeding compared to traditional batch culture, achieving $157.5 \mathrm{~g} / \mathrm{L}$ of $\mathrm{L}(+)$ lactic 


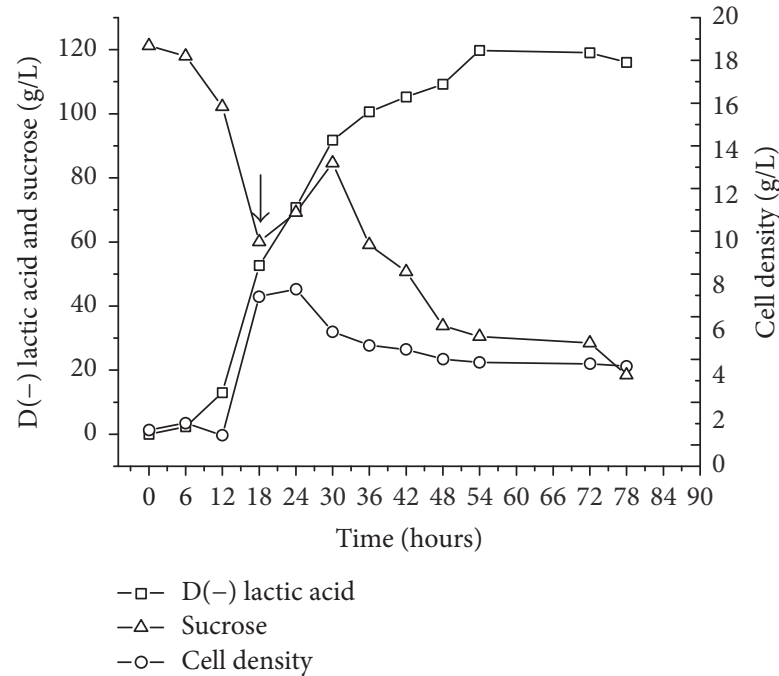

(a)

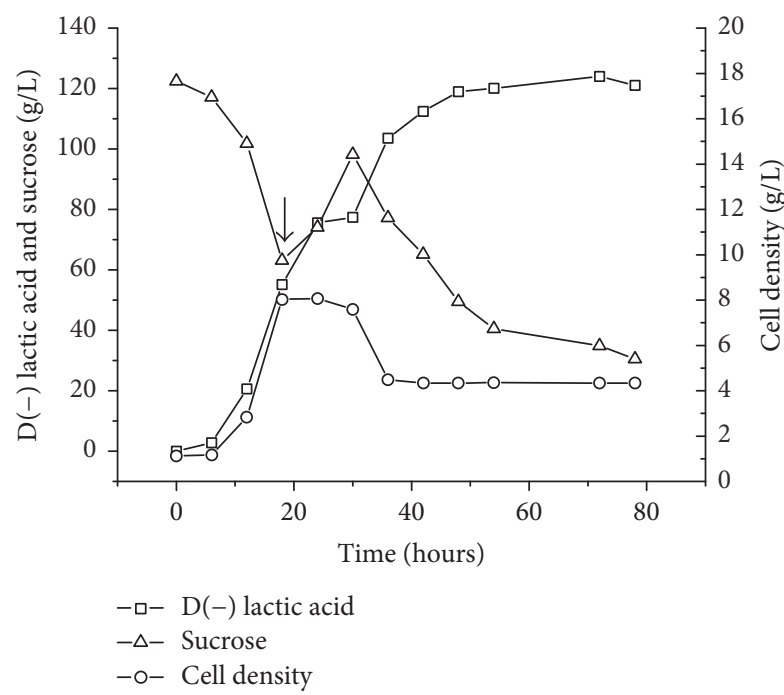

(b)

FIgURE 6: Time courses of sucrose consumption, $\mathrm{D}(-)$ lactic acid production, and cell growth in constant feed rate (a) and exponential fedbatch fermentation (b) by $S$. nakayamae. Experimental conditions: medium containing $35 \mathrm{~g} / \mathrm{L}$ of yeast extract and $7.5 \mathrm{~mL} / \mathrm{L}$ of GYP salts and crystallized sugar (as required); $\mathrm{pH} 6.0, \mathrm{NaOH} 10 \mathrm{~N}$ as controlling agent, temperature at $35^{\circ} \mathrm{C}, 125 \mathrm{rpm}$, and $20 \%$ of inoculum (v/v).

acid and productivity of $1.88 \mathrm{~g} / \mathrm{L} \cdot \mathrm{h}$ by Lactobacillus casei after $84 \mathrm{~h}$ of fermentation [40].

Except for the three-pulse feeding strategy, all other fed-batch strategies were able to increase the production and productivity of $\mathrm{D}(-)$ lactic acid when compared to batch fermentation (Figure 5(a)), which achieved maximum production and productivity of $106.95 \mathrm{~g} / \mathrm{L}$ and $2.67 \mathrm{~g} / \mathrm{L} \cdot \mathrm{h}$, respectively.

The fed-batch process could increase the total substrate content in the bioreactor by maintaining a low substrate concentration during fermentation and avoiding the inhibitory effects of sugar on lactic acid production as well as reducing the negative effects of osmotic pressure on bacterial cells. Other advantages of this process are higher cell concentration and productivity as well as a high titer of lactic acid production at the end of the fermentation process. The final product was not an inhibitory factor, as the lactic acid was presented as a salt (sodium lactate) when $\mathrm{NaOH}$ was used as the neutralizing agent. However, the osmotic pressure may be high at the end of the process, which can lead to a reduction in lactic acid production. This decline also could be related to decreasing metabolic potential of an aging microbial biocatalyst, as reported before by Ou et al., 2011 [41]. This paper is a part of a doctoral thesis [41].

\section{Conclusion}

$\mathrm{D}(-)$ lactic acid was successfully produced by $S$. nakayamae using fermentation under optimized conditions. The experimental design was very useful for determining the optimal concentrations of constituents that have significant effects on $\mathrm{D}(-)$ lactic acid production. This study has shown that $\mathrm{NaOH}$ is an effective, environmentally friendly $\mathrm{pH}$ controlling agent. Moreover, $\mathrm{pH}$, temperature, agitation, and inoculum size all exerted a significant influence on the production process. The fed-batch process was able to increase both the production and productivity of $\mathrm{D}(-)$ lactic acid. These findings demonstrate that $S$. nakayamae is a promising strain for $\mathrm{D}(-)$ lactic acid production.

\section{Conflicts of Interest}

The authors declare that there are no conflicts of interest regarding the publication of this paper.

\section{Acknowledgments}

The authors are grateful to the São Paulo Research Foundation (FAPESP), Braskem, and the National Council for Scientific and Technological Development (CNPq process302935/2015-0) for fellowships and financial support.

\section{References}

[1] T. Ghaffar, M. Irshad, Z. Anwar et al., "Recent trends in lactic acid biotechnology: a brief review on production to purification," Journal of Radiation Research and Applied Sciences, vol. 7, no. 2, pp. 222-229, 2014.

[2] C. Gao, C. Ma, and P. Xu, "Biotechnological routes based on lactic acid production from biomass," Biotechnology Advances, vol. 29, no. 6, pp. 930-939, 2011.

[3] M. A. Abdel-Rahman, Y. Tashiro, and K. Sonomoto, "Recent advances in lactic acid production by microbial fermentation processes," Biotechnology Advances, vol. 31, no. 6, pp. 877-902, 2013.

[4] A. Corma Canos, S. Iborra, and A. Velty, "Chemical routes for the transformation of biomass into chemicals," Chemical Reviews, vol. 107, no. 6, pp. 2411-2502, 2007. 
[5] Y. Tokiwa and B. P. Calabia, "Biological production of functional chemicals from renewable resources," Canadian Journal of Chemistry, vol. 86, no. 6, pp. 548-555, 2008.

[6] J. R. M. Almeida, L. C. L. Fávaro, and B. F. Quirino, "Biodiesel biorefinery: Opportunities and challenges for microbial production of fuels and chemicals from glycerol waste," Biotechnology for Biofuels, vol. 5, article no. 48, 2012.

[7] Y. Tokiwa and B. P. Calabia, "Biodegradability and biodegradation of poly(lactide)," Applied Microbiology and Biotechnology, vol. 72, no. 2, pp. 244-251, 2006.

[8] A. Södergård and M. Stolt, "Properties of lactic acid based polymers and their correlation with composition," Progress in Polymer Science (Oxford), vol. 27, no. 6, pp. 1123-1163, 2002.

[9] K. Madhavan Nampoothiri, N. R. Nair, and R. P. John, "An overview of the recent developments in polylactide (PLA) research," Bioresource Technology, vol.101, no. 22, pp. 8493-8501, 2010.

[10] C. Idler, J. Venus, and B. Kamm, "Microorganisms for the Production of Lactic Acid and Organic Lactates," in Microorganisms in Biorefineries, vol. 26 of Microbiology Monographs, pp. 225273, Springer Berlin Heidelberg, Berlin, Heidelberg, 2015.

[11] A. Von Wright, L. Axelsson, S. Lahtinen, A. C. Ouwehand, S. Salminen, and A. von Wright, "LA bacteria - microbiological and functional aspects," in LA Bacteria Microbiological And Functional Aspects, A. Von Wright, L. Axelsson, S. Lahtinen, A. C. Ouwehand, S. Salminen, and A. von Wright, Eds., pp. 1-16, CRC Press/Taylor Francis Group, Boca Raton, 2012.

[12] R. Datta and M. Henry, "Lactic acid: recent advances in products, processes and technologies-a review," Journal of Chemical Technology and Biotechnology, vol. 81, no. 7, pp. 11191129, 2006.

[13] J. Narita, S. Nakahara, H. Fukuda, and A. Kondo, "Efficient production of L-(+)-lactic acid from raw starch by Streptococcus bovis 148," Journal of Bioscience and Bioengineering, vol. 97, no. 6, pp. 423-425, 2004.

[14] Y. Li, A. Shahbazi, K. Williams, and C. Wan, "Separate and concentrate lactic acid using combination of nanofiltration and reverse osmosis membranes," Applied Biochemistry and Biotechnology, vol. 147, no. 1-3, pp. 1-9, 2008.

[15] S. Zhou, T. B. Causey, A. Hasona, K. T. Shanmugam, and L. O. Ingram, "Production of optically pure D-lactic acid in mineral salts medium by metabolically engineered Escherichia coli W3110," Applied and Environmental Microbiology, vol. 69, no. 1, pp. 399-407, 2003.

[16] S. Saitoh, N. Ishida, T. Onishi et al., "Genetically engineered wine yeast produces a high concentration of L-lactic acid of extremely high optical purity," Applied and Environmental Microbiology, vol. 71, no. 5, pp. 2789-2792, 2005.

[17] R. P. John, K. M. Nampoothiri, and A. Pandey, "Solid-state fermentation for L-lactic acid production from agro wastes using Lactobacillus delbrueckii," Process Biochemistry, vol. 41, no. 4, pp. 759-763, 2006.

[18] R. Ganguly, P. Dwivedi, and R. P. Singh, "Production of lactic acid with loofa sponge immobilized Rhizopus oryzae RBU2-10," Bioresource Technology, vol. 98, no. 6, pp. 1246-1251, 2007.

[19] W. H. Holzapfel and S. J. Botha, "Physiology of Sporolactobacillus strains isolated from different habitats and the indication of in vitro antagonism against Bacillus species," International Journal of Food Microbiology, vol. 7, no. 2, pp. 161-168, 1988.

[20] D. C. Montgomery, Design and Analysis of Experiments, John Wiley \& Sons, 5th edition, 2012.
[21] Z. M. Nor, M. I. Tamer, J. M. Scharer, M. Moo-Young, and E. J. Jervis, "Automated fed-batch culture of Kluyveromyces fragilis based on a novel method for on-line estimation of cell specific growth rate," Biochemical Engineering Journal, vol. 9, no. 3, pp. 221-231, 2001.

[22] R. Auras, L.-T. Lim, S. E. M. Selke, and H. Tsuji, "Preface," Poly(Lactic Acid): Synthesis, Structures, Properties, Processing, and Applications, pp. xvii-xix, 2010.

[23] N. Assavasirijinda, D. Ge, B. Yu, Y. Xue, and Y. Ma, "Efficient fermentative production of polymer-grade d-lactate by an engineered alkaliphilic Bacillus sp. strain under non-sterile conditions," Microbial Cell Factories, vol. 15, no. 1, article no. 3, 2016.

[24] H. W. Yien, T. J. Chen, W. C. Pan, and H. J. Wu, "Effects of neutralizing agents on lactic acid production by sweet potato starch," J. Microbiol. Biotechnol, vol. 26, pp. 437-441, 2010.

[25] S. Nakano, C. U. Ugwu, and Y. Tokiwa, "Efficient production of d-(-)-lactic acid from broken rice by Lactobacillus delbrueckii using $\mathrm{Ca}(\mathrm{OH}) 2$ as a neutralizing agent," Bioresource Technology, vol. 104, pp. 791-794, 2012.

[26] R. N. Shreve and J. A. Brink, Chemical Process Industries, McGraw-Hill, New York, 1st edition, 1977.

[27] Y. Liu, W. Gao, X. Zhao et al., "Pilot scale demonstration of d-lactic acid fermentation facilitated by $\mathrm{Ca}(\mathrm{OH}) 2$ using a metabolically engineered Escherichia coli," Bioresource Technology, vol. 169, pp. 559-565, 2014.

[28] S. D. Yuwono and T. Kokugan, "Study of the effects of temperature and $\mathrm{pH}$ on lactic acid production from fresh cassava roots in tofu liquid waste by Streptococcus bovis," Biochemical Engineering Journal, vol. 40, no. 1, pp. 175-183, 2008.

[29] B. Zhao, L. Wang, F. Li et al., "Kinetics of D-lactic acid production by sporolactobacillus sp. strain CASD using repeated batch fermentation," Bioresource Technology, vol. 101, no. 16, pp. 64996505, 2010.

[30] L. Wang, B. Zhao, F. Li et al., "Highly efficient production of d-lactate by Sporolactobacillus sp. CASD with simultaneous enzymatic hydrolysis of peanut meal," Applied Microbiology and Biotechnology, vol. 89, no. 4, pp. 1009-1017, 2011.

[31] A. H. Jawad, A. F. M. Alkarkhi, O. C. Jason, A. M. Easa, and N. A. Nik Norulaini, "Production of the lactic acid from mango peel waste-factorial experiment," Journal of King Saud University-Science, vol. 25, no. 1, pp. 39-45, 2013.

[32] K. Hofvendahl and B. Hahn-Hägerdal, "Factors affecting the fermentative lactic acid production from renewable resources," Enzyme and Microbial Technology, vol. 26, no. 2-4, pp. 87-107, 2000.

[33] C. J. B. de Lima, L. F. Coelho, and J. Contiero, "The use of response surface methodology in optimization of lactic acid production: Focus on medium supplementation, temperature and pH control," Food Technology and Biotechnology, vol. 48, no. 2, pp. 175-181, 2010.

[34] P. S. Panesar, J. F. Kennedy, C. J. Knill, and M. Kosseva, "Production of L(+) Lactic Acid using Lactobacillus casei from Whey," Brazilian Archives of Biology and Technology, vol. 53, no. 1, pp. 219-226, 2010.

[35] G. Shi, G. Wang, X. Chen, and C. Li, "Optically pure L-lactic acid production directly from leftover bits and pieces of potato starch using an amylolytic pellet-form complex Rhizopus oryzae ASC081," Journal of Applied Science and Engineering, vol. 16, no. 2, pp. 205-210, 2013.

[36] Z. Bai, Z. Gao, J. Sun, B. Wu, and B. He, "D-Lactic acid production by Sporolactobacillus inulinus YBS1-5 with simultaneous 
utilization of cottonseed meal and corncob residue," Bioresource Technology, vol. 207, pp. 346-352, 2016.

[37] D.-M. Bai, Q. Wei, Z.-H. Yan, X.-M. Zhao, X.-G. Li, and S.-M. $\mathrm{Xu}$, "Fed-batch fermentation of Lactobacillus lactis for hyperproduction of L-lactic acid," Biotechnology Letters, vol. 25, no. 21, pp. 1833-1835, 2003.

[38] C. Kotzamanidis, T. Roukas, and G. Skaracis, "Optimization of lactic acid production from beet molasses by Lactobacillus delbrueckii NCIMB 8130," World Journal of Microbiology and Biotechnology, vol. 18, no. 5, pp. 441-448, 2002.

[39] M. P. Bernardo, L. F. Coelho, D. C. Sass, and J. Contiero, "L-(+)Lactic acid production by Lactobacillus rhamnosus B103 from dairy industry waste," Brazilian Journal of Microbiology, vol. 47, no. 3, pp. 640-646, 2016.

[40] S. Ding and T. Tan, "l-lactic acid production by Lactobacillus casei fermentation using different fed-batch feeding strategies," Process Biochemistry, vol. 41, no. 6, pp. 1451-1454, 2006.

[41] M. S. Ou, L. O. Ingram, and K. T. Shanmugam, "L(+)-Lactic acid production from non-food carbohydrates by thermotolerant Bacillus coagulans," Journal of Industrial Microbiology and Biotechnology, vol. 38, no. 5, pp. 599-605, 2011. 

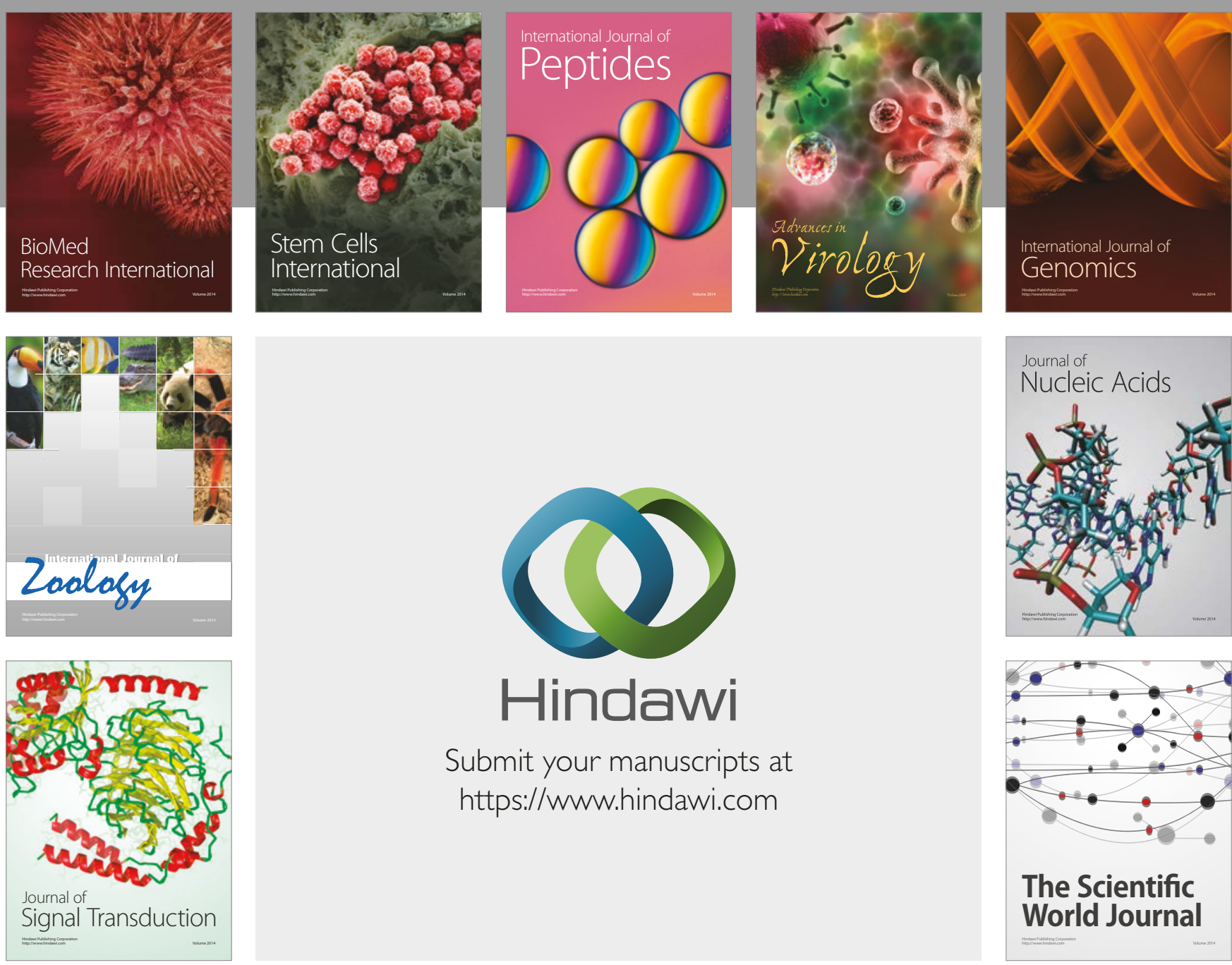

Submit your manuscripts at

https://www.hindawi.com
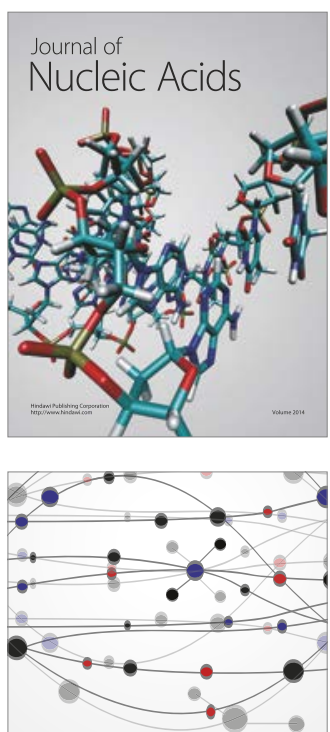

The Scientific World Journal

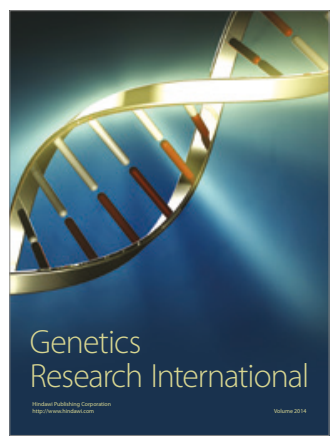

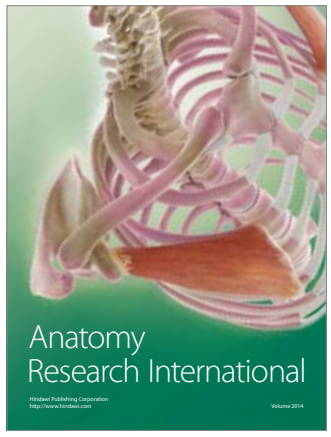

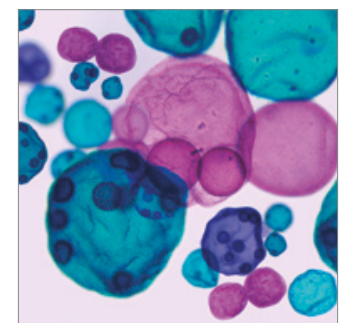

International Journal of Microbiology
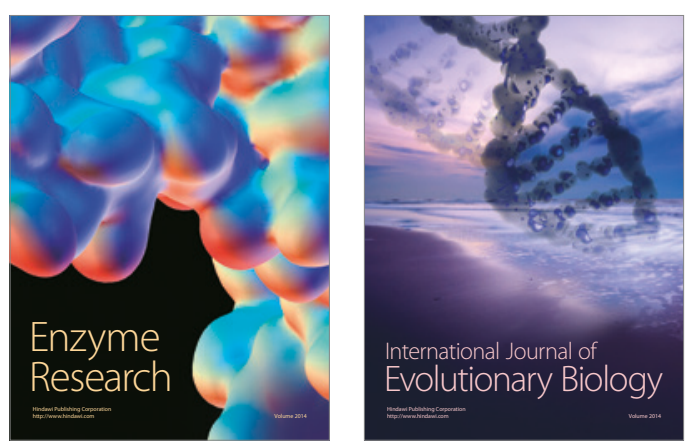
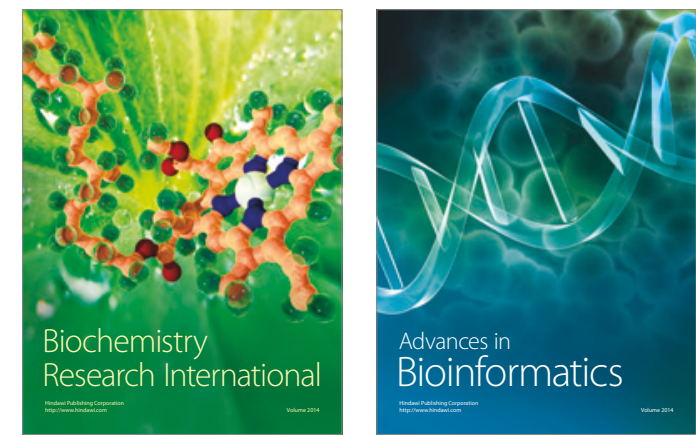

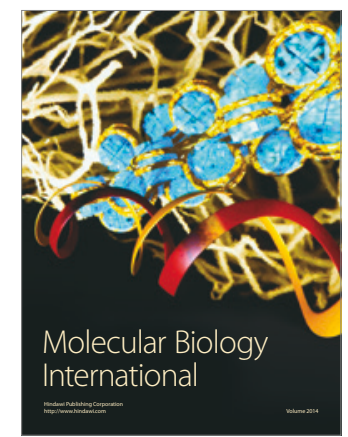

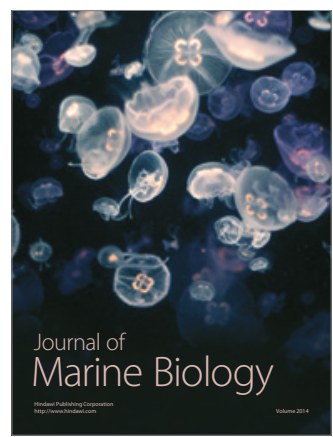

